\title{
Lung Cancer pN2 TNM Finding v6 and v7
}

National Cancer Institute

\section{Source}

National Cancer Institute. Lung Cancer pN2 TNM Finding v6 and v7. NCI Thesaurus. Code C60975.

Lung cancer with metastasis to ipsilateral mediastinal and/or subcarinal lymph nodes. (from AJCC 6th and 7th Eds.) 